www.volsu.ru

DOI: https://doi.org/10.15688/jvolsu3.2017.3.15

UDC 332.1

LBC 65.04

\title{
INDUSTRIAL POLICY OF REGIONS OF THE NORTH CAUCASIAN FEDERAL DISTRICT IN THE CONTEXT OF GEOECONOMIC CHALLENGES ${ }^{1}$
}

\author{
Natalya N. Kiseleva \\ North Caucasian Institute - Branch of Russian Presidential Academy of National Economy \\ and Public Administration, Pyatigorsk, Russian Federation \\ Anna A. Orlyanskaya \\ North Caucasian Institute - Branch of Russian Presidential Academy of National Economy \\ and Public Administration, Pyatigorsk, Russian Federation \\ Natalya V. Borovikova \\ North Caucasian Institute - Branch of Russian Presidential Academy of National Economy \\ and Public Administration, Pyatigorsk, Russian Federation
}

\begin{abstract}
The article provides a short review of influence of geoeconomic restrictions on the economy and industrial policy of the Russian Federation. The authors mention the list of economically restricted companies with the indication of their industry affiliation. The characteristic of import dependence scales in key industries of the Russian economy is given. The mechanism of influence of geoeconomic restrictions on economic and social situation in Russia is shown on the example of the food market. It is proved that the agro-industrial complex couldn't replenish the shortage at the domestic food market. The authors also point to strengths and weaknesses of import substitution policy in the economy and the social sphere of national economy. The main directions of import substitution policy in the Russian Federation are revealed with the indication of standard and legal documents, in which they are enshrined. The comparative analysis of import substitution plans of regions of the North Caucasian Federal District is carried out. The plans include such provisions as branch priorities, accounting of the developed branch structure of economy, strengths and weaknesses. From the authors' viewpoint, the import substitution plans of the Republics of Dagestan, Karachay-Cherkess Republic, the Republic of Northern Ossetia, the Chechen Republic are the most developed, as they take into account branch structure and promote regional growth. In these documents the directions of further deepening of regional specialization of an access into the markets of other regions of Russia are proved. It is noted that there are measures of regional policy, which have been used within the last decades and have not proved their efficiency. The authors make a valid conclusion about the insufficient innovation of regional plans of import substitution in the North Caucasian Federal District that hinders development and search of a niche for each of the regions in the system of national and international division of labour.
\end{abstract}

ПРОМЫШЛЕННАЯ ПОЛИТИКА РЕГИОНОВ СЕВЕРО-КАВКАЗСКОГО ФЕДЕРАЛЬНОГО ОКРУГА В КООРДИНАТАХ ГЕОЭКОНОМИЧЕСКИХ ВЫЗОВОВ ${ }^{1}$

\author{
Наталья Николаевна Киселева \\ Северо-Кавказский институт - филиал РАНХиГС, г. Пятигорск, Российская Федерация
}




\author{
Анна Александровна Орлянская \\ Северо-Кавказский институт - филиал РАНХиГС, г. Пятигорск, Российская Федерация
}

Наталья Владимировна Боровикова

Северо-Кавказский институт - филиал РАНХиГС, г. Пятигорск, Российская Федерация

\begin{abstract}
Аннотация. В статье дан краткий обзор влияния геоэкономических ограничений на экономику и промышленную политику Российской Федерации. Приведен перечень компаний с указанием отраслевой принадлежности, в отношении которых были применены экономические ограничения. Дана характеристика масштабов импортозависимости в ключевых отраслях российской экономики. Показан механизм влияния геоэкономических ограничений на экономическую и социальную ситуацию в России на примере продовольственного рынка. Обосновано, что агропромышленный комплекс не смог восполнить возникший дефицит на внутреннем продовольственном рынке. Выделены сильные и слабые стороны политики импортозамещения в экономике и социальной сфере национальной экономики. Конкретизированы основные направления политики импортозамещения в Российской Федерации с указанием нормативно-правовых документов, в которых они закреплены. Проведен сопоставительный анализ планов импортозамещения регионов Северо-Кавказского федерального округа: отраслевых приоритетов, учета сложившейся отраслевой структуры экономики, сильных и слабых сторон. С точки зрения авторов, наиболее проработаны, учитывают отраслевую структуру и способствуют региональному росту планы импортозамещения Республики Дагестан, Карачаево-Черкесской Республики, Республики Северная Осетия - Алания, Чеченской Республики. В данных документах обоснованы направления дальнейшего углубления региональной специализации выхода на рынки других регионов России. Отмечено наличие используемых в течение последних десятилетий и не доказавших свою эффективность мер региональной политики. Обоснован вывод о недостаточной инновационности региональных планов импортозамещения в Северо-Кавказском федеральном округе, препятствующей преодолению догоняющего развития и поиску ниши каждого из регионов в системе национального и международного разделения труда.

Ключевые слова: регион, промышленность, импортозамещение, промышленная политика, отраслевые приоритеты.
\end{abstract}

Геополитические и геоэкономические вызовы, с которыми сталкивается российская экономика и общество в последние годы, существенно обострили тепротиворечия, которые были заложены в предшествующие десятилетия экономической эволюции Российской Федерации.

Экономические ограничения в связи с реакцией ряда государств на присоединение Крыма к России коснулись конкретных физических лиц и ведущих компаний российской экономики (см. табл. 1).

В дальнейшем вплоть до настоящего времени список российских компаний, подпавших под экономические ограничения, видоизменялся и расширялся. В результате санкций оказалась нарушенной выстроенная в течение последних двух десятилетий схема участия российской экономики в международном разделении труда.

На рисунке 1 видны масштабы зависимости экономики России от импорта в стратегических отраслях экономики.

Разумеется, сложившаяся экономическая ситуация может крайне негативно сказаться на экономической безопасности и конкурентоспособ- ности нашей страны. В ответ на действия стран мира в августе 2014 г. властями России было введено эмбарго на импорт продовольственных товаров из стран, которые ввели ограничения против Российской Федерации. В основном это касалось стран Европейского союза, многие из которых до этого поставляли значительные объемы сельхозпродуктов в нашу страну. Экономические последствия продовольственного эмбарго для российского рынка были частично сглажены за счет переориентации на поставки из стран Таможенного союза, Азии и Латинской Америки. Еще до конца 2014 г. был увеличен объем поставок из Бразилии, Аргентины и Ирана. В июне 2016 г. В. Путин продлил ответноепродуктовое эмбарго России до 1 января 2018 г. [8].

По мнению специального докладчика ООН И. Джазаири, финансовые потери стран, вводивших антироссийские санкции, в два раза превышают убытки России. По его словам, антироссийские санкции обошлись различным государствам в более чем 100 млрд долларов. Сумму потерь России представитель ООН оценил в 52-55 млрд долларов [6]. 
Российские компании, в отношении которых применены санкции в 2014 г.

\begin{tabular}{|l|l|}
\hline \multicolumn{1}{|c|}{ Компания } & \multicolumn{1}{|c|}{ Профиль деятельности } \\
\hline ОАО «Концерн “Калашников”» & $\begin{array}{l}\text { Производитель боевого, спортивного и охотничьего оружия, } \\
\text { станков и инструментов }\end{array}$ \\
\hline $\begin{array}{l}\text { ОАО «Конструкторское бюро приборо- } \\
\text { строения имени академика А.Г. Шипунова» }\end{array}$ & $\begin{array}{l}\text { Разработчик противотанковых ракетных комплексов, систем } \\
\text { ПВО, стрелково-пушечного и гранатометного вооружения }\end{array}$ \\
\hline $\begin{array}{l}\text { ОАО «Военно-промышленная корпорация } \\
\text { “Научно-производственное объединение } \\
\text { машиностроения”» }\end{array}$ & $\begin{array}{l}\text { Разработчик ракетной техники, спутников и пилотируемых } \\
\text { космических кораблей }\end{array}$ \\
\hline ОАО «Концерн ПВО “Алмаз - Антей”» & $\begin{array}{l}\text { Группа предприятий, разрабатывающая и выпускающая сред- } \\
\text { ства противовоздушной и противоракетной обороны }\end{array}$ \\
\hline $\begin{array}{l}\text { ОАО «Концерн “Радиоэлектронные техно- } \\
\text { логии”» (КРЭТ) }\end{array}$ & $\begin{array}{l}\text { Управляющая компания, в состав которой входят предприятия, } \\
\text { разрабатывающие и выпускающие средства радиоэлектронной } \\
\text { борьбы и авионики }\end{array}$ \\
\hline ОАО «Роснефть» & $\begin{array}{l}\text { Добыча нефти и природного газа } \\
\text { Разработчик и производитель комплексов связи }\end{array}$ \\
\hline $\begin{array}{l}\text { ОАО «Концерн “Созвездие”» «Научно-производственная корпора- } \\
\text { ция “Уралвагонзавод”» }\end{array}$ & $\begin{array}{l}\text { Производство железнодорожной, строительной и военной тех- } \\
\text { ники, в том числе танки Т-90 }\end{array}$ \\
\hline $\begin{array}{l}\text { ОАО «Объединенная судостроительная } \\
\text { корпорация» }\end{array}$ & $\begin{array}{l}\text { Консолидирует около 80 \% отечественного судостроительного } \\
\text { комплекса }\end{array}$ \\
\hline $\begin{array}{l}\text { ОАО «Объединенная авиастроительная } \\
\text { корпорация» (ОАК) }\end{array}$ & $\begin{array}{l}\text { Холдинг, объединяющий около 30 компаний авиапромышлен- } \\
\text { ного комплекса РФ, в том числе «Сухой», «Туполев», «ОКБ } \\
\text { Яковлева», «МиГ» }\end{array}$ \\
\hline ОАО «РТ-Станкоинструмент» & $\begin{array}{l}\text { Производство станкоинструментальной продукции } \\
\text { Производство полимерных композиционных материалов и из- } \\
\text { делий }\end{array}$ \\
\hline \begin{tabular}{l} 
ОАО «РТ-Химкомпозит» \\
\hline
\end{tabular}
\end{tabular}

Примечание. Составлено авторами по: [1].

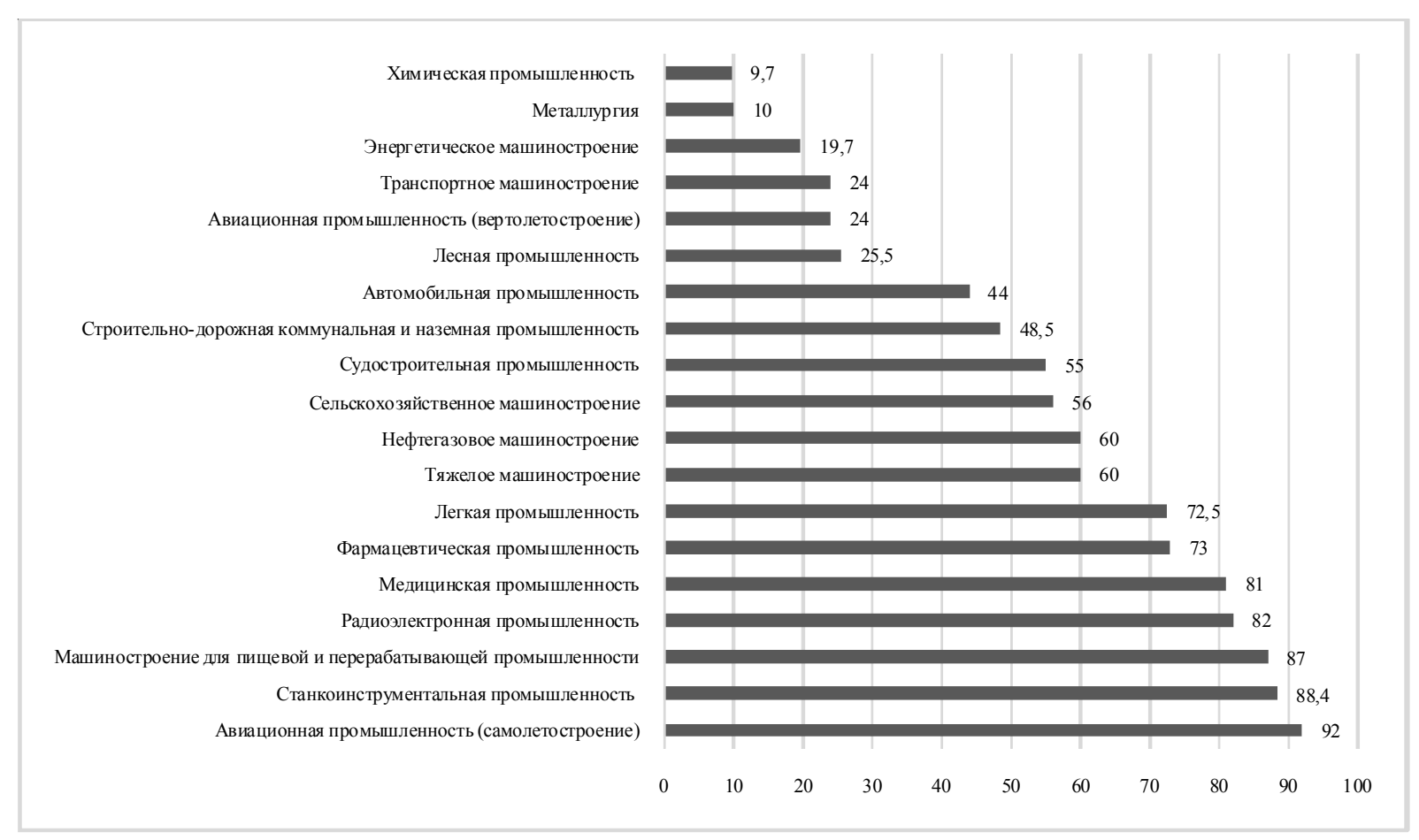

Рис. 1. Степень импортозависимости отраслей российской экономики

Примечание. Составлено авторами по: [7]. 


\section{СОЦИАЛЬНО-ЭКОНОМИЧЕСКОЕ РАЗВИТИЕ РЕГИОНОВ}

Меры ограничительного характера на ввоз продовольствия из ряда государств, несмотря на усилия Правительства России по переориентации в сотрудничестве на другие страны, привели к дефициту на рынке (рис. 2).

В этой ситуации агропромышленный комплекс нашей страны оказался не в состоянии заместить импорт по ряду категорий товаров. Объемы выпуска по отраслям, по сути, остались прежними. Возникший дефицит на рынке мяса был немного компенсирован за счет увеличения объемов производства свинины.

Сложившаяся классическая ситуация дефицита не могла не привести к росту цен. На рисунке 3 представлено сравнение цен на продовольственном рынке в декабре 2013 и декабре 2014 годов.

Обращает на себя внимание рост цен на молоко и молочную продукцию. Проведенный анализ подтверждает актуальность и необхо- димость ускоренного развития агропромышленного комплекса России для обеспечения импортозамещения на внутреннем рынке и эффективного использования природных ресурсов нашей страны.

Объемы импорта по итогам первых четырех месяцев 2015 г. сократились примерно на 36-38 \% по сравнению с аналогичным периодом 2014 года. Наиболее сильное сокращение импорта наблюдалось в отрасли пищевых продуктов, включая напитки и табачные изделия.

В сложившейся ситуации логичным было объявление правительством курса на импортозамещение. Политика импортозамещающей индустриализации не нова в мировой практике. К ней прибегли власти стран Латинской Америки, Мексики, Индии, Аргентины, Турции и других государств. Они получили как положительные, так и отрицательные примеры влияния политики импортоза-

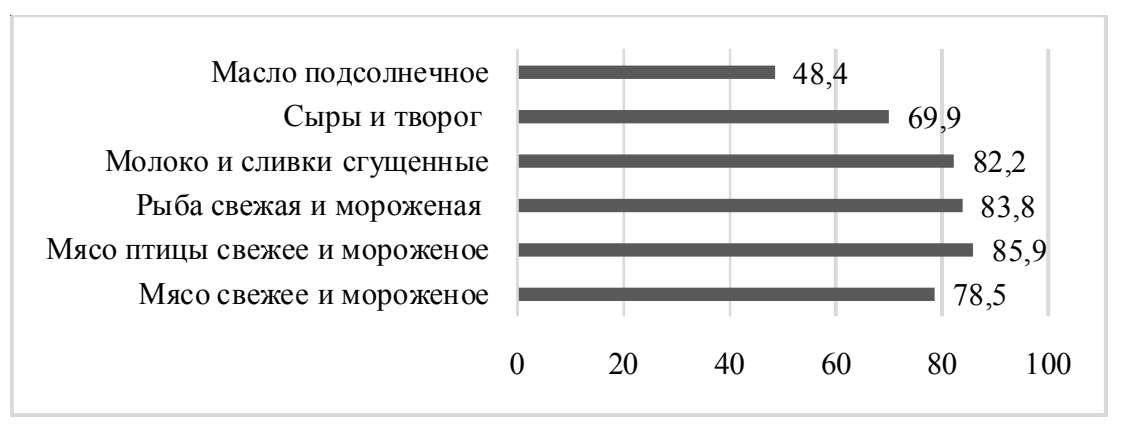

Рис. 2. Объемы импорта отдельных продовольственных товаров в натуральном выражении в 2014 г., в \% к объемам 2013 г.

Примечание. Составлено авторами по: [5].

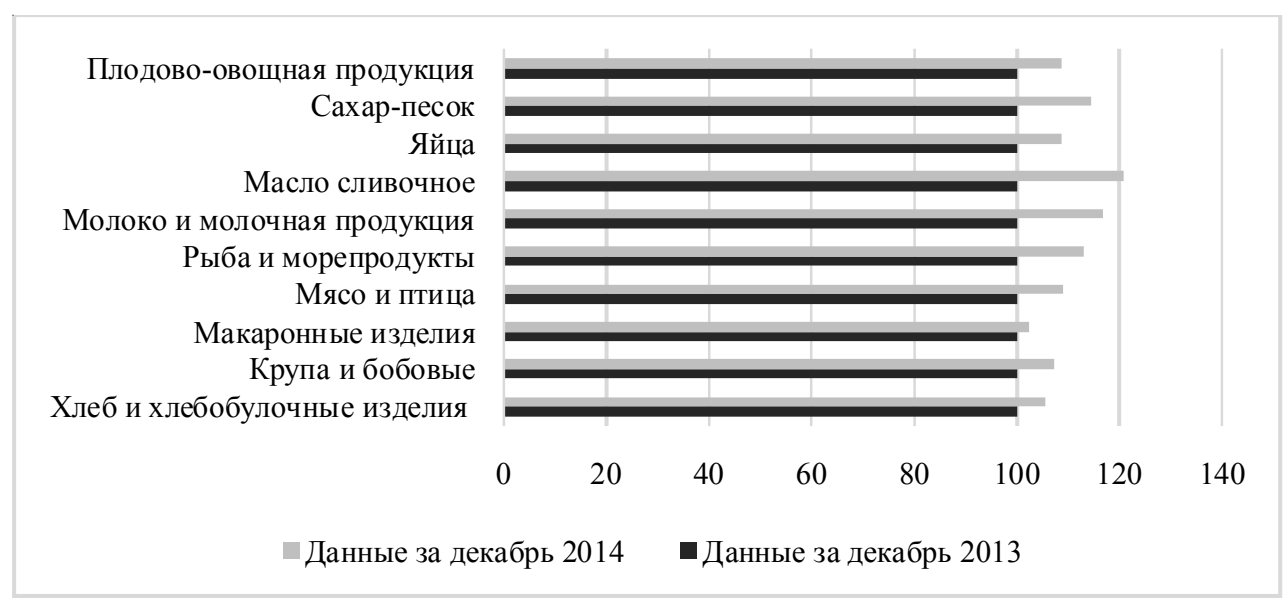

Рис. 3. Сравнение цен на отдельные группы продовольственных товаров в декабре 2013 г. и декабре 2014 г. в России, в \% к уровню 2013 г.

Примечание. Составлено авторами по: [5]. 
мещения на экономику [2-4]. Иногда вследствие государственной поддержки отмечалось искажение инвестиционных стимулов. Частным предприятиям становилось выгодно производство, стоимость факторов которого превосходила стоимость продукции, которую они производили. Подобная ситуация отмечалась, в частности, в советской и российской нефтепереработке.

Политика импортозамещающей индустриализации вследствие наращивания фискального и внешнего дисбалансов приводила к кризисам внешнего долга при резком прекращении потока капитала [9]. Так произошло в ряде стран Латинской Америки.

Кроме того, в качестве негативного последствия политики импортозамещения экономисты отмечают потери общественного благосостояния вследствие недостаточной интеграции в международное разделение труда.

Сторонники политики импортозамещения указывают на то, что при ее использовании отмечается ускоренный рост производительности в целевых отраслях, рост экономики в целом, рост занятости. Это приводит к выводу о том, что при принятии решения о реализации политики импортозамещения необходимо выработать модель, приемлемую для конкретной страны, и это позволит достичь определенных экономических результатов [10].

В качестве приоритетных отраслей для импортозамещения Министерством промышленности и торговли Российской Федерации в 2014-2015 гг. выделены: нефтегазовое машиностроение, химическая промышленность, легкая промышленность, автомобильная промышленность, машиностроение для пищевой и перерабатывающей промышленности, станкоинструментальная промышленность, цветная металлургия, черная металлургия, энергетическое машиностроение, кабельная и электротехническая промышленность, тяжелое машиностроение, медицинская промышленность, фармацевтическая промышленность, лесопромышленный комплекс, производство строительно-дорожной, коммунальной и наземной аэродромной техники, сельскохозяйственное и лесное машиностроение, транспортное машиностроение, судостроение, радиоэлектронная промышленность, авиационная промышленность. По каждому из дан- ных направлений в 2015 г. приказами Минпромторга утверждены соответствующие планы действий. Были также утверждены «План мероприятий (“дорожная карта”) по снижению зависимости от импорта в сфере обеспечения катализаторами предприятий нефтепереработки и нефтехимии», «План мероприятий (“дорожная карта") по содействию импортозамещению в сельском хозяйстве на 20142015 гг.», «Отраслевой план мероприятий по импортозамещению в нефтеперерабатывающей и нефтехимической отраслях промышленности Российской Федерации».

Аналитики отмечают, что данные документы ориентированы на краткосрочные горизонты развития. Кроме того, важно, чтобы в результате импортозамещения отрасль стала конкурентоспособной на мировом рынке, а не просто могла заменить импорт в условиях административных ограничений на ввоз.

Согласно поручению Правительства Российской Федерации в контексте приоритетов федеральной политики регионы Северо-Кавказского федерального округа разработали и приняли к реализации свои планы по обеспечению импортозамещения (см. табл. 2). Обобщенно они включают следующие разделы:

- мероприятия общеорганизационного и нормативного характера;

- мероприятия по содействию реализации инвестиционных проектов;

- меры, направленные на реализацию механизма контроля за выполнением регионального плана по импортозамещению;

- контрольные показатели реализации регионального плана по импортозамещению.

Слабой стороной практически всех региональных планов импортозамещения в регионах Северо-Кавказского федерального округа является недостаточная проработка конкретных мер по привлечению иногда достаточно масштабных инвестиционных вложений. Размыта ответственность должностных лиц за реализацию планов. Нередко в качестве ответственных по отдельным позициям плана указаны хозяйствующие субъекты, которым предполагается оказывать государственную поддержку. Не до конца понятен механизм возложения на них ответственности за реализацию отдельных направлений региональной политики. 
Анализ содержания и качества планов импортозамещения в регионах Северо-Кавказского федерального округа

\begin{tabular}{|c|c|c|c|c|}
\hline Регионы & $\begin{array}{l}\text { Отраслевые } \\
\text { приоритеты }\end{array}$ & Сильные стороны & Слабые стороны & $\begin{array}{c}\text { Учет сложившейся отраслевой } \\
\text { структуры экономики }\end{array}$ \\
\hline $\begin{array}{l}\text { Республи- } \\
\text { ка Даге- } \\
\text { стан }\end{array}$ & $\begin{array}{l}\text { Авиастроение, судо- } \\
\text { строение, нефтегазовое } \\
\text { машиностроение, хи- } \\
\text { мическая промышлен- } \\
\text { ность, производство } \\
\text { техники для сельского } \\
\text { хозяйства и АПК }\end{array}$ & $\begin{array}{l}\text { Направлен на импор- } \\
\text { тозамещение на внут- } \\
\text { реннем рынке страны } \\
\text { в отраслях, наиболее } \\
\text { зависимых от импор- } \\
\text { та. Проработан }\end{array}$ & & $\begin{array}{l}\text { Учитывает. Способствует } \\
\text { развитию конкурентных } \\
\text { преимуществ экономики } \\
\text { региона }\end{array}$ \\
\hline $\begin{array}{l}\text { Республи- } \\
\text { ка Ингу- } \\
\text { шетия }\end{array}$ & $\begin{array}{l}\text { Светодиодные техноло- } \\
\text { гии, изделия из пласт- } \\
\text { масс, легкая промыш- } \\
\text { ленность }\end{array}$ & $\begin{array}{l}\text { В целевых показате- } \\
\text { лях указаны конкрет- } \\
\text { ные объемы выпуска } \\
\text { по отраслям за каж- } \\
\text { дый год реализации } \\
\text { плана }\end{array}$ & $\begin{array}{l}\text { Содержит не- } \\
\text { большое коли- } \\
\text { чество кон- } \\
\text { кретных про- } \\
\text { ектных пред- } \\
\text { ложений }\end{array}$ & $\begin{array}{l}\text { Мог быть усилен ком- } \\
\text { плексный подход к разви- } \\
\text { тию экономики республи- } \\
\text { ки. План, скорее, включает } \\
\text { отдельные разрозненные } \\
\text { инвестиционные проекты }\end{array}$ \\
\hline $\begin{array}{l}\text { Кабарди- } \\
\text { но-Бал- } \\
\text { карская } \\
\text { Республика }\end{array}$ & $\begin{array}{l}\text { Сельское хозяйство, } \\
\text { пищевая промышлен- } \\
\text { ность }\end{array}$ & $\begin{array}{l}\text { Большое количество } \\
\text { проектов по созданию } \\
\text { специализированных } \\
\text { комплексов для хране- } \\
\text { ния сельхозпродукции } \\
\end{array}$ & $\begin{array}{l}\text { Мало внимания } \\
\text { уделено разви- } \\
\text { тию сельхозпе- } \\
\text { реработки }\end{array}$ & $\begin{array}{l}\text { План почти не учитывает } \\
\text { промышленный потенциал } \\
\text { региона. Направлен на раз- } \\
\text { витие одного отраслевого } \\
\text { комплекса - АПК }\end{array}$ \\
\hline $\begin{array}{l}\text { Карачаево- } \\
\text { Черкесская } \\
\text { Республика }\end{array}$ & $\begin{array}{l}\text { Легкая промышлен- } \\
\text { ность, промышлен- } \\
\text { ность строительных } \\
\text { материалов, агропро- } \\
\text { мышленный комплекс }\end{array}$ & $\begin{array}{l}\text { Подробно описаны } \\
\text { ключевые инвестици- } \\
\text { онные проекты с ука- } \\
\text { занием географии } \\
\text { сбыта продукции. От- } \\
\text { дельно выделен план } \\
\text { по импортозамеще- } \\
\text { нию в агропромыш- } \\
\text { ленном комплексе }\end{array}$ & & $\begin{array}{l}\text { Учитывает. Способствует } \\
\text { развитию конкурентных } \\
\text { преимуществ экономики } \\
\text { региона }\end{array}$ \\
\hline $\begin{array}{l}\text { Республи- } \\
\text { ка Север- } \\
\text { ная Осе- } \\
\text { тия - Ала- } \\
\text { ния }\end{array}$ & $\begin{array}{l}\text { Машиностроение, про- } \\
\text { мышленность строи- } \\
\text { тельных материалов, } \\
\text { пищевая промышлен- } \\
\text { ность и производство } \\
\text { напитков, сельское хо- } \\
\text { зяйство, туризм } \\
\end{array}$ & $\begin{array}{l}\text { В составе плана есть } \\
\text { перечень проектов, } \\
\text { представленных вуза- } \\
\text { ми республики и со- } \\
\text { держащих инноваци- } \\
\text { онные разработки }\end{array}$ & & $\begin{array}{l}\text { Учитывает. Способствует } \\
\text { развитию конкурентных } \\
\text { преимуществ экономики } \\
\text { региона }\end{array}$ \\
\hline $\begin{array}{l}\text { Чеченская } \\
\text { Республика }\end{array}$ & $\begin{array}{l}\text { Транспортное машино- } \\
\text { строение, нефтегазовое } \\
\text { машиностроение, про- } \\
\text { изводство сельхозтех- } \\
\text { ники, электротехниче- } \\
\text { ская промышленность, } \\
\text { медицинская промыш- } \\
\text { ленность, легкая про- } \\
\text { мышленность, про- } \\
\text { мышленность строи- } \\
\text { тельных материалов, } \\
\text { лесопереработка }\end{array}$ & $\begin{array}{l}\text { Комплексное развитие } \\
\text { промышленного про- } \\
\text { изводства республики }\end{array}$ & & $\begin{array}{l}\text { Проработан план импорто- } \\
\text { замещения в сфере про- } \\
\text { мышленности. Возможно } \\
\text { было бы также проработать } \\
\text { комплексные меры импор- } \\
\text { тозамещения в сельском } \\
\text { хозяйстве }\end{array}$ \\
\hline $\begin{array}{l}\text { Ставро- } \\
\text { польский } \\
\text { край }\end{array}$ & $\begin{array}{l}\text { Сельское хозяйство, } \\
\text { химическая промыш- } \\
\text { ленность, машино- } \\
\text { строение }\end{array}$ & $\begin{array}{l}\text { Подробно раскрыты } \\
\text { цели и принципы плана } \\
\text { импортозамещения, } \\
\text { конкретизированы } \\
\text { краевые программы, за } \\
\text { счет средств которых } \\
\text { планируется реализа- } \\
\text { ция мероприятий плана }\end{array}$ & $\begin{array}{l}\text { Нет новаций ни } \\
\text { по характеру } \\
\text { проектов, ни по } \\
\text { отраслевым } \\
\text { приоритетам } \\
\text { плана }\end{array}$ & $\begin{array}{l}\text { План учитывает сложив- } \\
\text { шуюся отраслевую струк- } \\
\text { туру экономики, однако } \\
\text { слабо прослеживаются на- } \\
\text { правления для прорывного } \\
\text { роста краевой экономики }\end{array}$ \\
\hline
\end{tabular}

Примечание. Составлено авторами. 
Большинство предлагаемых в планах импортозамещения мер региональной политики традиционны на протяжении не одного десятилетия [2;3]. Многие не демонстрировали ранее высокой эффективности. Также в большинстве случаев традиционны предлагаемые направления региональной экономики.

Планы по импортозамещению на 20162020 гг. приняты отдельным документом в Ставропольском крае, Кабардино-Балкарской Республике, Республике Ингушетия, Республике Северная Осетия - Алания, КарачаевоЧеркесской Республике, Чеченской Республике [4].

В Республике Дагестан план импортозамещения в промышленности и агропромышленном комплексе принят в составе комплекса первоочередных мер по обеспечению опережающего развития экономики и социальной стабильности Республики Дагестан.

На наш взгляд, одним из самых проработанных региональных планов импортозамещения является документ, подготовленный органами исполнительной власти Республики Дагестан. Он направлен на решение проблемы импортозамещения в стране в отраслях, которые пострадали от экономических ограничений. Отдельная часть документа посвящена совершенствованию институциональной среды региональной политики импортозамещения. В частности, предлагается создать Межведомственную рабочую группу по мониторингу развития ситуации в социальноэкономической сфере и реализации Плана действий Правительства Республики Дагестан, направленных на обеспечение стабильного социально-экономического развития Республики Дагестан на 2015-2017 гг., Планов мероприятий по содействию импортозамещению, а также создать Экспертный совет по импортозамещению в промышленности и АПК Республики Дагестан и утвердить его состав.

Проработаны меры по развитию агропромышленного комплекса: восстановление племенной базы, диверсификация растениеводства и животноводства. Предлагаемые в плане импортозамещения проекты рассредоточены по всей территории республики.

Интересна идея властей Республики Северная Осетия - Алания, включивших в план импортозамещения проекты, предложенные вузами. Они касаются сферы IT, переработки отходов, промышленности строительных материалов.

При обосновании инвестиционных проектов в плане импортозамещения КарачаевоЧеркесской Республики особое внимание уделено связи этих проектов со специализацией экономики региона, также описанию потенциальных рынков сбыта производимой продукции.

В достаточной мере проработан и будет способствовать диверсификации экономики региона план импортозамещения в промышленности Чеченской Республики.

Общим недостатком всех планов импортозамещения северокавказских регионов является их невысокая инновационность. Преодоление догоняющего развития и занятие собственной ниши в системе российского и международного разделения труда невозможно без ориентации на самые передовые разработки и решения в промышленности.

\section{ПРИМЕЧАНИЕ}

${ }^{1}$ Исследование выполнено при финансовой поддержке РФФИ в рамках научного проекта № 16-32-00024.

\section{СПИСОК ЛИТЕРАТУРЫ}

1. Бодрунов, С. Д. Грядущее. Новое индустриальное общество: перезагрузка / С. Д. Бодрунов. - М. : Культурная революция, 2016. - 349 с.

2. Галушкин, В. И. Кооперация и интеграция в агропромышленном комплексе современной России: от традиционализма к модернизации / В. И. Галушкин, И. В. Митрофанова, Л. В. Объедкова // Национальные интересы: приоритеты и безопасность. -2009 . - № 1. - С. 10-19.

3. Липина, С. А. Приоритеты развития Республик Северного Кавказа / С. А. Липина // Региональная экономика: теория и практика. - 2008. № 16. - С. 3-9.

4. Митрофанова, И. В. Модернизация АПК Юга России в новых геополитических и геоэкономических условиях / И. В. Митрофанова, Н. П. Иванов, И. А. Митрофанова // Экономическое стратегирование в новых реалиях: механизмы, инструменты, технологии : монография / под общ. ред. проф. Л. Г. Матвеевой, О. А. Черновой. - Таганрог : Изд-во ЮФУ, 2016. - С. 89-94.

5. Официальный сайт Федеральной службы государственной статистики. - Электрон. текстовые 
дан. - Режим доступа: http://www.gks.ru (дата обращения: 13.09.2017). - Загл. с экрана.

6. Потери России и мира от санкционных войн оценили в три ВВП Эфиопии. - Электрон. текстовые дан. - Режим доступа: https://enta.ru/news/ 2017/04/28/losses/ (дата обращения: 23.09.2017). Загл. с экрана.

7. Приложение 3 к Плану содействия импортозамещению в промышленности / Министерство промышленности и торговли РФ. - 2015. - Электрон. текстовые дан. - Режим доступа: http://www. sovel.org/files/News/Prilozhenie_3.pdf(дата обращения: 12.09.2017). - Загл. с экрана.

8. Путин продлил эмбарго, введенное в ответ на санкции Запада до 2018 года. - Электрон. текстовые дан. - Режим доступа: https://ria.ru/politics/ 20160629/1454435636.html (дата обращения: 01.10.2017). - Загл. с экрана.

9. Helpman, E. The Mystery of Economic Growth / E. Helpman. - Cambridge : Harvard University Press, 2004. -240 p.

10. Rodrik, D. Industrial Policy for the twentyfirst century. (November 2004) / D. Rodrik // CEPR Discussion Paper. - № 4767. - Electronic text data. Mode of access: http://ssrn.com/abstract $=666808$ (date of access: 11.09.2017). - Title from screen.

\section{REFERENCES}

1. Bodrunov S.D. Gryadushchee. Novoe industrialnoe obshchestvo: perezagruzka [The Upcoming. New Industrial Society: Reset]. Moscow, Kulturnaya revolyutsiya Publ., 2016. 349 p.

2. Galushkin V.I., Mitrofanova I.V., Obyedkova L.V. Kooperatsiya i integratsiya $\mathrm{v}$ agropromyshlennom komplekse sovremennoy Rossii: ot traditsionalizma $\mathrm{k}$ modernizatsii [Cooperation and Integration in AgroIndustrial Complex of Modern Russia: from Traditionalism to Modernization]. Natsionalnye interesy: prioritety $i$ bezopasnost [National Interests: Priorities and Safety], 2009, no. 1, pp. 10-19.
3. Lipina S.A. Prioritety razvitiya Respublik Severnogo Kavkaza [Priorities of Development of the Republics of the North Caucasus]. Regionalnaya ekonomika: teoriya i praktika [Regional Economy: Theory and Practice], 2008, no. 16, pp. 3-9.

4. Mitrofanova I.V., Ivanov N.P., Mitrofanova I.A. Modernizatsiya APK Yuga Rossii v novykh geopoliticheskikh i geoekonomicheskikh usloviyakh [Modernization of Agro-Industrial Complex of the South of Russia in New Geopolitical and Geoeconomic Conditions]. Matveeva L.G., Chernova O.A., eds. Ekonomicheskoe strategirovanie v novykh realiyakh: mekhanizmy, instrumenty, tekhnologii: monografiya [The Economic Strategies in New Realities: Mechanisms, Tools, Technologies. Monograph]. Taganrog, Izd-vo YuFU, 2016, pp. 89-94.

5. Ofitsialnyy sayt Federalnoy sluzhby gosudarstvennoy statistiki [Official Site of Federal State Statistics Service]. URL: http://www.gks.ru.

6. Poteri Rossii i mira ot sanktsionnykh voyn otsenili v tri VVP Efiopii [Losses of Russia and the World Caused by Sanctions Make Three GDP of Ethiopia]. URL: https://lenta.ru/news/2017/04/28/ losses/.

7. Prilozhenie 3 k Planu sodeystviya importozameshcheniyu v promyshlennosti [Appendix 3 to the Plan of Assistance to Import Substitution in the Industry]. Ministerstvo promyshlennosti i torgovli $R F$ [Ministry of Industry and Trade of the Russian Federation], 2015. URL: http://www.sovel.org/files/ News/Prilozhenie_3.pdf.

8. Putin prodlil embargo, vvedennoe $v$ otvet na sanktsii Zapada do 2018 goda [Putin Has Prolonged the Embargo Imposed in Response to Sanctions of the West till 2018]. URL: https://ria.ru/ politics/20160629/1454435636.html.

9. Helpman E. The Mystery of Economic Growth. Cambridge, Harvard University Press, 2004. $240 \mathrm{p}$.

10. Rodrik D. Industrial Policy for the twenty-first century (November 2004). CEPR Discussion Paper, no. 4767 . URL: http://ssrn.com/abstract $=666808$.

\section{Information about the Authors}

Natalya N. Kiseleva, Doctor of Sciences (Economics), Professor, Deputy Director, North Caucasian Institute - Branch of Russian Presidential Academy of National Economy and Public Administration, Dunaevskogo St., 5, 357500 Pyatigorsk, Russian Federation, Kiseleva-n-n@yandex.ru.

Anna A. Orlyanskaya, Candidate of Sciences (Economics), Associate Professor, Department of Economy and Antimonopoly Regulation, North Caucasian Institute - Branch of Russian Presidential Academy of National Economy and Public Administration, Dunaevskogo St., 5, 357500 Pyatigorsk, Russian Federation, orlyanna@yandex.ru.

Natalya V. Borovikova, Postgraduate Student, Department of Economy and Antimonopoly Regulation, North Caucasian Institute - Branch of Russian Presidential Academy of National 
Н.Н. Киселева, А.А. Орлянская, Н.В. Боровикова. Промышленная политика регионов

Economy and Public Administration, Dunaevskogo St., 5, 357500 Pyatigorsk, Russian Federation, bor79@yandex.ru.

\section{Информация об авторах}

Наталья Николаевна Киселева, доктор экономических наук, профессор, заместитель директора, Северо-Кавказский институт - филиал РАНХиГС, ул. Дунаевского, 5, 357500 г. Пятигорск, Российская Федерация, Kiseleva-n-n@yandex.ru.

Анна Александровна Орлянская, кандидат экономических наук, доцент кафедры экономики и антимонопольного регулирования, Северо-Кавказский институт - филиал РАНХиГС, ул. Дунаевского, 5, 357500 г. Пятигорск, Российская Федерация, orlyanna@yandex.ru.

Наталья Владимировна Боровикова, аспирант кафедры экономики и антимонопольного регулирования, Северо-Кавказский институт - филиал РАНХиГС, ул. Дунаевского, 5, 357500 г. Пятигорск, Российская Федерация, bor79@yandex.ru. 